\title{
Analisis Penggunaan Antibiotik pada Pasien Rawat Inap Bedah dengan Menggunakan Defined Daily Dose dan Drug Utilization 90\% di Rumah Sakit Universitas Airlangga
}

\author{
Novan Y. I. Pratama ${ }^{1}$, Budi Suprapti ${ }^{1,2}$, Azril O. Ardiansyah ${ }^{3}$, Dewi W. Shinta ${ }^{1,2}$ \\ ${ }^{1}$ Departemen Farmasi Klinis Fakultas Farmasi, Universitas Airlangga Surabaya, Indonesia, \\ ${ }^{2}$ Instalasi Farmasi Rumah Sakit Pendidikan Universitas Airlangga, Surabaya, Indonesia, \\ ${ }^{3}$ Staf Medis Fungsional Bedah Rumah Sakit Pendidikan Universitas Airlangga, \\ Surabaya, Indonesia
}

\begin{abstract}
Abstrak
Tingkat kematian akibat resistensi terhitung cukup tinggi dan hal ini disebabkan tingginya angka ketidaktepatan dalam terapi antibiotik. Penelitian Antimicrobial Resistance in Indonesia (AMRIN) menunjukkan $42 \%$ penggunaan antibiotik terindikasi tidak tepat pada pasien bedah. Penggunaan antibiotik secara bijak merupakan solusi atas masalah resistensi antibiotik. World Health Organization (WHO) dan Kementerian Kesehatan Republik Indonesia merekomendasikan penggunaan metode Anatomical Therapeutic Chemical/Defined Daily Dose (ATC/DDD) untuk menilai kuantitas penggunaan antibiotik. Penelitian ini bertujuan untuk mengetahui nilai DDD dan Drug Utilization (DU) $90 \%$ dari antibiotik. Penelitian ini merupakan penelitian cross-sectional dengan pengambilan data secara retrospektif yang dilakukan pada November 2016-April 2017 di Rumah Sakit Universitas Airlangga dan data dianalisis menggunakan metode DDD dan DU 90\%. Sampel diambil dengan cara total sampling. Sebanyak 463 pasien menjadi sampel pada penelitian ini, dengan 381 pasien mendapatkan antibiotik profilaksis dan 82 pasien mendapatkan antibiotik terapi. Sefazolin merupakan antibiotik profilaksis yang memiliki DDD tertinggi yaitu 69,08/100 operasi dengan lama pemberian sebagian besar dihentikan dalam waktu kurang dari 24 jam post-operasi $(82,41 \%)$. Antibiotik profilaksis yang masuk segmen DU $90 \%$ adalah sefazolin dan seftriakson. Antibiotik terapi yang memiliki DDD tertinggi adalah seftriakson dengan 52,62/100 patient-days dan antibiotik yang masuk segmen DU 90\% adalah seftriakson, metronidazol, sefazolin dan meropenem.
\end{abstract}

Kata kunci: Antibiotik, defined daily dose, DU 90\%, pasien bedah

\section{Analysis of Antibiotic Use in Surgical Inpatients Using Defined Daily Dose and Drug Utilization $\mathbf{9 0 \%}$ at Universitas Airlangga Hospital}

\begin{abstract}
Antibiotic resistance is causing high mortality rates throughout the world and resulted from inappropriate use of antibiotics therapy. Antimicrobial Resistance in Indonesia (AMRIN) study showed that there were $42 \%$ of inappropriate antibiotic use in surgical patients. Prudent antibiotics use is one of the solution to resolve this problem. Ministry of Health of Indonesia and World Health Organization (WHO) recommend Anatomical Therapeutic Chemical/Defined Daily Dose (ATC/DDD) as quantitative evaluation of antibiotics to evaluate the appropriateness of antibiotics use. This study aimed to determine the value of DDD and Drug Utilization (DU) $90 \%$ of antibiotics used in surgical patients. This research was conducted using cross-sectional design with retrospective data collection during November 2016April 2017 at Universitas Airlangga Hospital, and data were analyzed using the DDD method and DU $90 \%$. Sample were collected using total sampling method. A total of 463 patients included as samples in this study, of which 381 patients received prophylactic antibiotic and 82 patients received therapeutic antibiotics. Cefazolin was prophylactic antibiotic with highest DDD of 69.08/100 operations and duration of administration was mostly stopped in less than 24 hours post-operatively (82.41\%). Prophylactic antibiotics included in DU 90\% segment were cefazoline and ceftriaxone. Therapeutic antibiotic with highest DDD was ceftriaxone with 52.62/100 patient-days. Therapeutic antibiotics included in DU 90\% segment were ceftriaxone, metronidazole, cefazolin and meropenem.
\end{abstract}

Keywords: Antibiotic, defined daily dose, DU90\%, surgical inpatients

Korespondensi: Novan Y. I. Pratama, S.Farm., Apt., Departemen Farmasi Klinis Fakultas Farmasi, Universitas Airlangga, Surabaya, Jawa Timur 60286, Indonesia, email: novanyusufindra@gmail.com

Naskah diterima: 25 Juni 2019, Diterima untuk diterbitkan: 5 Desember 2019, Diterbitkan: 28 Desember 2019 


\section{Pendahuluan}

Saat ini, resistensi antibiotik adalah masalah terbesar dalam terapi infeksi. Mikroorganisme sebagian besar telah dapat beradaptasi dengan pemberian antibiotik sehingga antibiotik tidak lagi dapat membunuh bakteri tersebut. Pada negara-negara maju, tingkat kematian akibat resistensi terhitung cukup tinggi, contohnya tercatat 23.000 kematian per tahun di Amerika Serikat disebabkan oleh resistensi antibiotik, sedangkan di Eropa telah mencapai 25.000 kematian per tahun. ${ }^{1}$ Menurut data resistensi, sebanyak $70 \%$ bakteri telah resisten terhadap antibiotik yang sering digunakan di rumah sakit. $^{2}$

Studi Antimicrobial Resistance in Indonesia (AMRIN) yang dilakukan di Rumah Sakit dr. Kariadi dan RSUD dr. Soetomo menunjukkan bahwa sebesar $42 \%$ penggunaan antibiotik di rumah sakit terindikasi kurang tepat pada pasien bedah. ${ }^{3}$ Penelitian di beberapa negara menunjukkan ketidaktepatan penggunaan antibiotik profilaksis pada pasien bedah linear dengan peningkatan angka resistensi, lama rawat inap pasien, dan biaya perawatan. ${ }^{3-5}$

Beragam upaya telah dilakukan World Health Organization (WHO) untuk mengendalikan resistensi secara global. WHO telah membuat perencanaan aksi global untuk memerangi resistensi antibiotik dengan meningkatkan penggunaan antibiotik secara bijak dan dengan melakukan evaluasi penggunaan antibiotik. ${ }^{6}$ Evaluasi antibiotik dapat dilakukan secara kuantitatif dengan menggunakan Anatomical Therapeutic Chemical/Defined Daily Dose (ATC/DDD) dan secara kualitatif dengan metode Gyssens. ${ }^{7}$ Sistem ATC/DDD dapat digunakan untuk mengukur intensitas obat yang dikonsumsi secara luas di masyarakat sehingga penggunaan obat di suatu negara atau wilayah dapat dimonitor dengan baik. Data tersebut berguna untuk mengetahui perubahan penggunaan obat dari waktu ke waktu. Selain itu, data tersebut dapat pula digunakan untuk mengidentifikasi penggunaan obat yang salah (misuse), kurang (underuse), dan berlebihan (overuse), dan untuk melakukan perbandingan penggunaan obat.

Evaluasi kuantitatif dengan menggunakan metode DDD merupakan sebuah upaya untuk meningkatkan penggunaan antibiotik secara bijak. ${ }^{6}$ Selain itu, metode ATC/DDD dapat dikombinasikan dengan Drug Utilization (DU) 90\% dalam rangka menentukan kelompok obat dengan pemakaian yang tinggi di rumah sakit. Nilai DU 90\% menjadi acuan data untuk melihat kualitas peresepan dan kepatuhan terhadap pedoman dan formularium. Dengan mengetahui nilai DU 90\%, dapat dilakukan evaluasi obat, pengendalian penggunaan obat, serta intervensi yang tepat apabila ditemukan ketidaksesuaian dengan formularium. Tujuan penelitian ini adalah untuk mengetahui nilai DDD dan DU 90\% dari antibiotik di Rumah Sakit Universitas Airlangga, Surabaya.

\section{Metode}

Penelitian ini merupakan penelitian crosssectional dengan pengambilan data secara retrospektif. Penelitian ini telah dinyatakan laik etik oleh Komite Etika dan Hukum Rumah Sakit Universitas Airlangga dengan nomor: 080/KEH/2017. Sampel penelitian ini adalah rekam medik pasien bedah di Instalasi Rawat Inap Rumah Sakit Universitas Airlangga pada bulan November 2016-April 2017.

Kriteria inklusi meliputi pasien rawat inap bedah yang menggunakan antibiotik dan berusia di atas 18 tahun, sedangkan kriteria eksklusi meliputi data pasien dari Kelompok Staf Medik (KSM) Ilmu Penyakit Dalam atau Intensive Care Unit (ICU) yang melakukan prosedur wound care/debridement karena komplikasi penyakit, pasien bedah rujukan dari rumah sakit lain, serta pasien dengan data penggunaan antibiotik yang tidak lengkap. Data yang diperoleh kemudian dilakukan perhitungan menggunakan satuan $\mathrm{DDD} / 100$ 
operasi untuk antibiotik profilaksis dan DDD/ 100 patient-days untuk antibiotik terapi. Segmen penggunaan antibiotik terbanyak ditetapkan menggunakan metode DU 90\% dengan mengurutkan penggunaan antibiotik dari presentase terbesar, lalu diambil segmen 90\%. Rumus perhitungan DDD/100 patient days adalah sebagai berikut: ${ }^{7}$

$$
\begin{aligned}
& \mathrm{DDD} 100 \\
& \text { /patient-days }
\end{aligned}=\frac{\mathrm{AB}(\text { gram }) \times 100}{\mathrm{DDD} \mathrm{WHO}(\text { gram }) \times \mathrm{LoS}}
$$

$\mathrm{AB}=$ Antibiotik yang digunakan pasien;

$\mathrm{DDD} \mathrm{WHO}=$ Standar defined daily dose $W H O$; $\mathrm{LoS}=$ Length of stay.

\section{Hasil}

Hasil penelitian menunjukkan bahwa dari 502 pasien yang memenuhi kriteria inklusi, sebanyak 39 pasien masuk kriteria eksklusi atau sebesar 7,7\% dari keseluruhan data yang diambil sehingga tidak akan memengaruhi integritas data. Jumlah sampel yang diperoleh adalah 463 pasien (Gambar 1); jumlah pasien yang mendapatkan antibiotik profilaksis yaitu 381 pasien $(82,29 \%)$, sedangkan jumlah pasien yang mendapatkan antibiotik terapi yaitu 82 pasien $(17,71 \%)$. Data demografi dapat dilihat pada Tabel 1 .

Pada penelitian ini, didapatkan nilai DDD serta DU 90\% antibiotik profilaksis maupun terapi. Jumlah pasien yang mendapat antibiotik profilaksis sebanyak 381 pasien, dengan total LoS pasien 1385 hari. Antibiotik profilaksis yang digunakan adalah sefazolin, seftriakson, sefuroksim, dan sefotaksim. Nilai DDD dan DU $90 \%$ dari masing-masing antibiotik dapat dilihat pada Tabel 2.

Rincian nilai DDD antibiotik profilaksis dapat dilihat pada masing-masing jenis bedah. Sefazolin merupakan antibiotik yang paling banyak digunakan pada bedah umum, ortopedi, gigi mulut, dan obgyn, sedangkan seftriakson terbanyak digunakan pada bedah

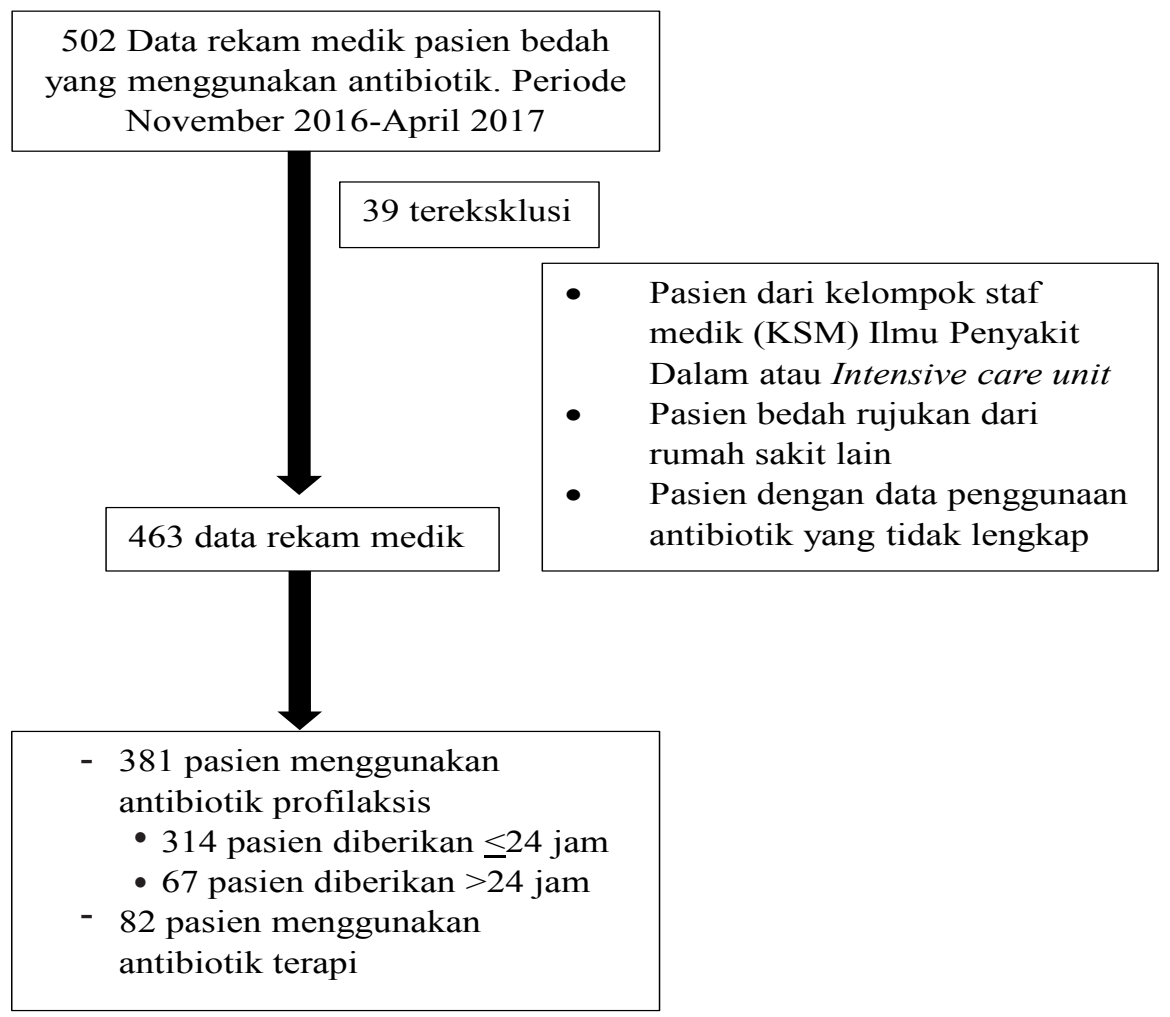

Gambar 1 Flowchart Pengambilan Data Penelitian 
Tabel 1 Data Demografi Pasien

\begin{tabular}{lcc}
\hline \multicolumn{1}{c}{ Karakteristik Pasien } & Jumlah Pasien & Persentase (\%) \\
\hline Jenis Kelamin & & \\
$\quad$ Laki-laki & 147 & 31,75 \\
$\quad$ Perempuan & 316 & 68,25 \\
Usia & & \\
$19-29$ tahun & 135 & 29,16 \\
$30-39$ tahun & 133 & 28,72 \\
$40-49$ tahun & 86 & 18,57 \\
$50-59$ tahun & 56 & 12,09 \\
$>60$ tahun & 53 & 11,46 \\
Lama Rawat Inap & & \\
1 hari & 13 & 3,00 \\
2 hari & 29 & 6,00 \\
3 hari & 176 & 38,00 \\
4 hari & 155 & 34,00 \\
5 hari & 50 & 11,00 \\
6 hari & 20 & 4,00 \\
$\quad 7$ hari & 20 & 4,00 \\
Indikasi Antibiotik & & \\
$\quad$ Antibiotik profilaksis & 381 & 82,29 \\
Antibiotik terapi & 82 & 17,71 \\
Lama Pemberian Profilaksis* & & \\
$<24$ jam & 314 & 82,41 \\
$>24$ jam & 67 & 17,59 \\
\hline
\end{tabular}

plastik, syaraf, urologi, thoraks kardiovaskular, serta telinga hidung dan tenggorokan (THT). Rincian nilai DDD pada setiap jenis bedah dapat dilihat pada Tabel 3.

Jumlah pasien yang mendapat antibiotik terapi yaitu 82 pasien dengan total LoS pasien 366 hari. Antibiotik terapi yang digunakan antara lain sefazolin, seftriakson, sefotaksim, seftazidim, levofloksasin, metronidazol, gentamisin, dan meropenem. Nilai DDD dan DU $90 \%$ dari masing-masing antibiotik dapat dilihat pada Tabel 4.

\section{Pembahasan}

Evaluasi kuantitatif penggunaan antibiotik dilakukan dengan menghitung DDD yang telah direkomendasikan oleh WHO. Penilaian dilakukan terhadap 463 rekam medik pasien bedah di Instalasi Rawat Inap Rumah Sakit Universitas Airlangga pada November 2016April 2017. Nilai DDD akan linear dengan tingginya penggunaan antibiotik: semakin kecil nilai DDD, artinya dokter lebih selekif dan mendekati prinsip penggunaan antibiotik

Tabel 2 Nilai DDD dan \% DU Antibiotik Profilaksis

\begin{tabular}{lccccc}
\hline \multicolumn{1}{c}{ Jenis Antibiotik } & Kode ATC & $\begin{array}{c}\text { DDD Standar } \\
\text { WHO (gram) }\end{array}$ & DDD Total & $\begin{array}{c}\text { DDD/100 } \\
\text { Operasi }\end{array}$ & \% DU \\
\hline Sefazolin & J01DB04 & 3 & 263,19 & 69,08 & $74,54^{*}$ \\
Seftriakson & J01DD04 & 2 & 80,38 & 21,10 & $22,77^{*}$ \\
Sefuroksim & J01DC02 & 3 & 7,75 & 2,03 & 2,19 \\
Sefotaksim & J01DD01 & 4 & 1,75 & 0,46 & 0,50 \\
& & Total & $\mathbf{3 5 3 , 0 7}$ & $\mathbf{9 2 , 6 7}$ & \\
\hline
\end{tabular}


Tabel 3 Nilai DDD dan \% DU Antibiotik Profilaksis

\begin{tabular}{lcccccccccc}
\hline $\begin{array}{c}\text { Jenis } \\
\text { Antibiotik }\end{array}$ & $\begin{array}{c}\text { Kode } \\
\text { ATC }\end{array}$ & $\begin{array}{c}\text { Bedah } \\
\text { Umum }\end{array}$ & $\begin{array}{c}\text { Orto- } \\
\text { pedi }\end{array}$ & THT & $\begin{array}{c}\text { Bedah } \\
\text { Plastik }\end{array}$ & $\begin{array}{c}\text { Bedah } \\
\text { Syaraf }\end{array}$ & $\begin{array}{c}\text { Uro- } \\
\text { logi }\end{array}$ & Obgyn & $\begin{array}{c}\text { Gigi } \\
\text { Mulut }\end{array}$ & $\begin{array}{c}\text { Bedah } \\
\text { TKV }+ \\
\text { Jantung }\end{array}$ \\
\hline Sefazolin & J01DB04 & 62,18 & 128,43 & 22,33 & 25,13 & 67 & - & 65,6 & 85,55 & - \\
Seftriakson & J01DD04 & 37,79 & 18,18 & 83,33 & 106,3 & 300 & 125 & 1,37 & - & 104,5 \\
Sefuroksim & J01DC02 & 5,80 & - & - & 6,25 & - & - & - & - & - \\
Sefotaksim & J01DD01 & - & - & - & - & - & - & 0,93 & - & - \\
\multicolumn{2}{c}{ Total } & $\mathbf{1 0 5 , 7 7}$ & $\mathbf{1 4 6 , 6 1}$ & $\mathbf{1 0 5 , 6 6}$ & $\mathbf{1 3 7 , 6 8}$ & $\mathbf{3 6 7}$ & $\mathbf{1 2 5}$ & $\mathbf{6 7 , 9}$ & $\mathbf{8 5 , 5}$ & $\mathbf{1 0 4 , 5}$ \\
\multicolumn{2}{c}{ Jumlah Pasien } & 112 & 44 & 6 & 8 & 1 & 2 & 188 & 9 & 11 \\
\hline
\end{tabular}

yang rasional.

Antibiotik profilaksis digunakan pada prosedur kategori bedah bersih yang memiliki risiko tinggi infeksi, bersih terkontaminasi, serta kontaminasi, sedangkan antibiotik terapi diindikasikan untuk kategori bedah kotor. ${ }^{8}$ Antibiotik profilaksis yang digunakan pada penelitian ini seluruhnya merupakan golongan sefalosporin. Sefazolin merupakan antibiotik profilaksis dengan nilai DDD terbesar yaitu DDD 69,08/100 operasi yang artinya pada setiap tindakan terdapat penggunaan rata-rata sefazolin 0,69 kali dari dosis DDD standar WHO yaitu 3 gram. Pada hasil penelitian ini, DU 90\% menunjukkan hanya sefazolin dan seftriakson yang masuk dalam DU $90 \%$.

Terdapat penelitian serupa yang membahas tentang penggunaan antibiotik profilaksis pada pasien bedah. Penelitian yang dilakukan oleh tim AMRIN pada tahun 2008 menunjukkan bahwa golongan sefalosporin merupakan antibiotik yang banyak diresepkan di bangsal bedah dengan DDD sebesar 16,4 DDD/100 hari rawat. ${ }^{3}$ Hal serupa juga ditemukan pada penelitian yang dilakukan di dua rumah sakit di Indonesia pada tahun $2016 .{ }^{9}$ Hal tersebut berbeda dengan hasil yang diperoleh dalam penelitian ini bahwa sefazolin lebih banyak diresepkan dibandingkan seftriakson. Menurut pedoman penggunaan antibiotik, golongan sefalosporin generasi pertama yaitu sefazolin telah direkomendasikan sebagai lini pertama sebagai antibiotik profilaksis sebab sefazolin memiliki spektrum yang baik untuk bakteri gram positif. ${ }^{7,8}$ Penelitian yang dilakukan di Iran, India dan Amerika melaporkan bahwa sefazolin digunakan sebagai pilihan utama untuk antibiotik profilaksis. ${ }^{10-12}$ Namun, pada penelitian ini dapat diketahui bahwa masih terdapat penggunaan antibiotik lain sebagai

Tabel 4 Nilai DDD dan \% DU Antibiotik Terapi

\begin{tabular}{lcccccc}
\hline Jenis Antibiotik & $\begin{array}{c}\text { Rute } \\
\text { Pemberian }\end{array}$ & Kode ATC & $\begin{array}{c}\text { DDD Standar } \\
\text { WHO (gram) }\end{array}$ & $\begin{array}{c}\text { DDD } \\
\text { Total }\end{array}$ & $\begin{array}{c}\text { DDD/100 } \\
\text { Patient-days }\end{array}$ & \% DU \\
\hline Seftriakson & IV & J01DD04 & 2,00 & 197,33 & 53,92 & $52,38^{*}$ \\
Metronidazol & IV & J01XD01 & 1,50 & 100,00 & 27,32 & $26,54^{*}$ \\
Sefazolin & IV & J01DB04 & 3,00 & 41,38 & 11,31 & $10,98^{*}$ \\
Meropenem & IV & J01DH02 & 2,00 & 12,00 & 3,28 & $3,19 *$ \\
Sefotaksim & IV & J01DD01 & 3,00 & 8,50 & 2,32 & 2,26 \\
Gentamisin & IV & J01GB03 & 0,24 & 7,00 & 1,91 & 1,86 \\
Seftazidim & IV & J01DD02 & 4,00 & 6,50 & 1,78 & 1,73 \\
Levofloksasin & IV & J01MA12 & 0,50 & 4,00 & 1,09 & 1,06 \\
& & & Total & $\mathbf{3 7 6 , 7 1}$ & $\mathbf{1 0 2 , 9 3}$ & \\
\hline
\end{tabular}


profilaksis yaitu seftriakson, sefuroksim, dan sefotaksim. Total DDD pada penelitian ini tercatat lebih rendah dibandingkan penelitian di Turki yaitu 92,67/100 operasi dibandingkan 305,7 DDD/100 operasi, yang menunjukkan bahwa total penggunaan antibiotik yang lebih rendah. ${ }^{13}$

Nilai DDD yang tinggi tercatat pada beberapa prosedur bedah, di antaranya bedah syaraf dengan total DDD 367/100 operasi, bedah ortopedi 146/100 operasi serta urologi $125 / 100$ operasi. Hal ini menunjukkan bahwa terdapat penggunaan antibiotik profilaksis yang diperpanjang ( $>24$ jam) atau dengan dosis yang tinggi untuk satu kali prosedur pembedahan. Jumlah antibiotik profilaksis yang diberikan lebih dari 24 jam tercatat sebanyak $17,59 \%$. Hal tersebut kemungkinan diakibatkan terdapat beberapa operasi dengan durasi yang panjang yang kemudian melebihi waktu paruh dari antibiotik atau disebabkan pendarahan pasien sebanyak lebih dari 1500 cc. ${ }^{14}$ Pada sebuah hasil survei yang dilakukan di China mengenai penggunaan antibiotik yang diperpanjang pada kasus bedah syaraf, telah dilaporkan bahwa sebanyak $71 \%$ dokter menyetujui bahwa antibiotik profilaksis yang diperpanjang perlu diberikan kepada pasien menggunakan drain, yaitu sebuah perangkat (biasanya berupa tabung) yang digunakan untuk mengambil cairan dari rongga tubuh bagian dalam. ${ }^{15}$ WHO menyebutkan bahwa tidak ada perbedaan signifikan pada angka kejadian Surgical Site Infection (SSI) antara penggunaan antibiotik profilaksis tunggal dengan yang diperpanjang pada pasien dengan menggunakan drain. Pemberian antibiotik profilaksis yang diperpanjang harus menjadi perhatian karena dapat berpotensi overuse dan dapat menjadi penyebab berkembangnya resistensi antibiotik, oleh sebab itu, pemberian harus dihentikan maksimal 24 jam setelah bedah (48 jam untuk bedah jantung) karena pemberian lebih dari 24 jam tidak memberikan peningkatan dalam outcome klinis pasien. ${ }^{16}$
Seftriakson merupakan antibiotik terapi dengan nilai DDD terbesar yaitu 53,64/100 patient-days, yang diikuti oleh metronidazol dengan nilai DDD 26,59/100 patient-days. Antibiotik terapi terbanyak ketiga adalah sefazolin dengan nilai DDD sebesar 10,94/100 patient-days. Antibiotik lain yang digunakan adalah meropenem, sefotaksim, gentamisin, seftazidim, dan levofloksasin yang memiliki nilai DDD kurang dari 5/100 patient-days. Sementara itu, hasil DU 90\% menunjukkan bahwa seftriakson, metronidazole, sefazolin dan meropenem masuk dalam segmen DU 90\%. Banyaknya variasi antibiotik menjadi penyebab insiden resistensi antibiotik dan hal ini dapat meningkatkan potensi munculnya resistensi pada antibiotik yang digunakan. ${ }^{17}$ Penelitian atau jurnal sebagai pembanding masih belum ditemukan sehingga tidak dapat dilakukan perbandingan kuantitas penggunaan antibiotik terapi.

Berdasarkan hasil penelitian ini, terdapat penggunaan obat antibiotik profilaksis yang diperpanjang atau cenderung banyak diresepkan dokter pada bedah syaraf dan ortopedi jika dilihat dari nilai DDD antibiotik. Hal ini harus menjadi perhatian sebab menjadi salah satu indikasi ketidaktepatan penggunaan antibiotik. Data perhitungan DDD ini diharapkan dapat menurunkan penggunaan antibiotik yang tidak tepat serta menjadi data awal untuk melakukan penelitian lanjutan tentang evaluasi kualitas penggunaan antibiotik menggunakan metode Gyssens, sehingga dapat segera dilakukan intervensi untuk meningkatkan rasionalitas penggunaan antibiotik dan untuk menekan angka resistensi.

Keterbatasan penelitian ini salah satunya terdapat pada penggunaan metode retrospektif yang memiliki kelemahan pada penulisan rekam medik yang tidak lengkap. Selain itu, minimnya literatur mengenai penelitian yang sama juga menjadi keterbatasan penelitian ini sehingga perbandingan nilai DDD tidak dapat dilakukan. 


\section{Simpulan}

Antibiotik profilaksis dengan nilai DDD terbesar adalah sefazolin dengan 69,08/100 operasi dan antibiotik profilaksis yang masuk dalam segmen DU 90\% adalah sefazolin dan seftriakson, sedangkan antibiotik terapi dengan nilai DDD terbesar adalah seftriakson dengan 53,64/100 patient-days dan antibiotik terapi yang masuk dalam segmen DU 90\% adalah seftriakson, metronidazol, sefazolin dan meropenem.

\section{Pendanaan}

Penelitian ini tidak didanai oleh sumber hibah manapun

\section{Konflik Kepentingan}

Seluruh penulis menyatakan tidak terdapat potensi konflik kepentingan dengan penelitian, kepenulisan (authorship), dan atau publikasi artikel ini.

\section{Daftar Pustaka}

1. Marston HD, Dixon DM, Knisely JM, Palmore TN, Fauci AS. Antimicrobial resistance. J Am Med Assoc. 2016;316 (11): 1193-204. doi: 10.1001/jama.2016.11764

2. Blair JM, Webber MA, Baylay AJ, Ogbolu DO, Piddock LJ. Molecular mechanisms of antibiotic resistance. Nat Rev Microbiol. 2015;13(1):42-51. doi: 10. 1038/nrmicro3380.

3. Hadi U, Duerink DO, Lestari ES, Nagelkerke NJ, Keuter M, In't Veld DH, et al. Audit of antibiotic prescribing in two governmental teaching hospitals in Indonesia. Clin Microbiol Infect. 2008; 14(7):698-707. doi: 10.1111/j.1469-0691 .2008.02014.x

4. Weiner LM, Webb AK, Limbago B, Dudeck MA, Patel J, Kallen AJ, et al.
Antimicrobial-resistant pathogens associated with healthcare-associated infections: Summary of data reported to the National Healthcare Safety Network at the Centers for Disease Control and Prevention, 2011-2014. Infect Control Hosp Epidemiol. 2016;37(11):1288-301. doi: 10.1017/ice.2016.174

5. İnan A, Dağlı Ö, Akçay SŞ, Engin DÖ, Karagül E, Özyürek SÇ. Antibiotic use and cost in a teaching hospital in İstanbul. J Microbiol Infect Dis. 2011;1(3):12833. doi: 10.5799/ahinjs.02.2011.03.0029

6. World Health Organization. Global action plan on antimicrobial resistance. Geneva: World Health Organization; 2015.

7. Kementerian Kesehatan Republik Indonesia. Pedoman pelayanan kefarmasian untuk terapi antibiotik Jakarta: Kementerian Kesehatan Republik Indonesia; 2011.

8. Chisholm-Burns MA, Schwinghammer TL, Wells BG, Malone PM, Kolesar JM, DiPiro JT. Pharmacoteraphy: A pathophysiologic approach, $7^{\text {th }}$ edition. New York: Mc Graw Hill Medical; 2016.

9. Herawati F, Yulia R, Hak E, Hartono AH, Michiels T, Woerdenbag HJ, et al. A retrospective surveillance of the antibiotics prophylactic use of surgical procedures in private hospitals in Indonesia. Hosp Pharm. 2019;54(5):323-9. doi: 10.1177/0 018578718792804

10. Foroutan B, Foroutan R. Perioperative antibiotic prophylaxis in elective surgeries in Iran. Med J Islam Repub Iran. 2014;28: 66.

11. Dhammi IK, U1 Haq R, Kumar S. Prophylactic antibiotics in orthopedic surgery. Indian J Orthop. 2015;(4):373-6. doi: 10.4103/0019-5413.159556

12. Ho VP, Nicolau DP, Dakin GF, Pomp A, Rich BS, Towe CW, Barie PS. Cefazolin dosing for surgical prophylaxis in morbidly obese patients. Surg Infect. 2012;13(1):337. doi: $10.1089 /$ sur.2010.097. 
13. Bozkurt F, Kaya S, Gulsun S, Tekin R, Deveci Ö, Dayan S, Hoşoglu S. Assessment of perioperative antimicrobial prophylaxis using ATC/DDD methodology. Int J Infect Dis. 2013;17(12):e1212-7. doi: 10.1016/j. ijid.2013.08.003.

14. Bratzler DW, Dellinger EP, Olsen KM, Perl TM, Auwaerter PG, Bolon MK, et al. Clinical practice guidelines for antimicrobial prophylaxis in surgery. Surg Infect. 2013;14(1):73-156. doi: 10.1089/ sur.2013.9999

15. Lewis A, Czeisler BM, Lord AS. Prolonged prophylactic antibiotics with neurosurgical drains and devices: Are we using them? Do we need them?. Am J Infect Control. 2016;44(12):1757-8. doi: 10.1016/j.ajic.2016.06.039

16. World Health Organization. Global guidelines for the prevention of surgical site infection. Geneva: World Health Organization; 2016.

17. Mahmudah F, Sumiwi SA, Hartini S. Studi penggunaan antibiotik berdasarkan ATC/DDD dan DU 90\% di bagian bedah digestif di salah satu rumah sakit di Bandung. Indones J Clin Pharm. 2016;5 (4):293-8. doi: 10.15416/ijcp.2016.5.4.293

(C) 2019 Pratama et al. The full terms of this license incorporate the Creative Common Attribution-Non Commercial License (https://creative commons.org/licenses/by-nc/4.0/). By accessing the work you hereby accept the terms. Non-commercial use of the work are permitted without any further permission, provided the work is properly attributed. 